\title{
FAKTOR-FAKTOR YANG MEMPENGARUHI AKSES PANGAN RUMAH TANGGA DI KELURAHAN TUMBANG RUNGAN KECAMATAN PAHANDUT KOTA PALANGKA RAYA
}

\author{
${ }^{1}$ Delika Parwati, ${ }^{2}$ Maleha, ${ }^{3}$ Tri Yuliana Eka Sintha
}

${ }^{1}$ Alumnus Program Studi Agribisnis Fakultas Pertanian Universitas Palangka Raya ${ }^{2,}{ }^{3}$ Staf Pengajar Program Studi Agribisnis Fakultas Pertanian Univesitas Palangka Raya

Email: yulianasintha@agb.upr.ac.id

\begin{abstract}
ABSTRAK
Tujuan dalam penelitian ini adalah: 1). Mengetahui akses pangan rumah tangga di Kelurahan Tumbang Rungan Kecamatan Pahandut Kota Palangka Raya dan 2). Mengetahui faktor-faktor yang mempengaruhi akses pangan rumah tangga di Kelurahan Tumbang Rungan Kecamatan Pahandut Kota Palangka Raya.

Metode yang digunakan untuk menjawab tujuan pertama adalah analisis kualitatif deskriptif dan untuk menjawab tujuan kedua menggunakan analisis kuantitatif (analisis regresi linear berganda). Hasil penelitian menunjukkan akses pangan rumah tangga di Kelurahan Tumbang Rungan dari hasil analisis skoring yang digunakan bahwa total skor rataan dari indikator akses pangan sebesar 66 yang artinya bahwa akses pangan rumah tangga dalam kondisi tinggi. Pada penilaian akses pangan di Kelurahan Tumbang Rungan, semua indikator berpengaruh terhadap akses pangan rumah tangga. Faktor-faktor yang mempengaruhi akses pangan rumah tangga di Kelurahan Tumbang Rungan, berdasarkan analisis regresi linear berganda diperoleh nilai koefisien determinasi $\left(\mathrm{R}^{2}\right)=0,501$ atau $50,1 \%$. Model yang digunakan dalam analisis ini berpengaruh sebesar $50,1 \%$ dan sisanya sebesar 49,9\% dipengaruhi oleh faktor lain yangtidak masuk dalam model yang digunakan. Hasil uji $F$ menunjukkan nilai $F_{\text {hitung }}=7,543$ lebih besar dari nilai $F_{\text {tabel }}=4,02$ pada taraf kepercayaan $99 \%$, sehingga faktor yang diujikan memiliki pengaruh secara simultan terhadap akses pangan rumah tangga di Kelurahan Tumbang Rungan Kecamatan Pahandut Kota Palangka Raya. Secara parsial, pendapatan dan pendidikan terakhir kepala keluarga berpengaruh nyata terhadap akses pangan rumah tangga di Kelurahan Tumbang Rungan yaitu pada taraf 95\% - 99\%, sedangkan yang tidak berpengaruh nyata terhadap akses pangan rumah tangga di Kelurahan Tumbang Rungan adalah umur dan jumlah anggota rumah tangga pada taraf kepercayaan $90 \%$.
\end{abstract}

Kata kunci: akses, pangan, rumahtangga

\section{ABSTRACT}

The objectives of this study are: 1). Knowing access to household food in Tumbang Rungan Village, Pahandut District, Palangka Raya City and 2). 


\begin{abstract}
Knowing the factors that affect household foo81d access in Tumbang Rungan Village, Pahandut District, Palangka Raya City. The method used to answer the first objective is descriptive qualitative analysis and to answer the second objective using quantitative analysis (multiple linear regression). The results showed that access to household food in Tumbang Rungan village from the results of the scoring analysis used that the total average score of the food access indicator was 66, which means that household food access was in high condition. In the assessment of access to food in Tumbang Rungan Village, all indicators affect household food access. Based on multiple linear regression analysis, the coefficient of determination $(\mathrm{R} 2)=0,501$ or $50,1 \%$. The model used in this analysis has an effect of $50,1 \%$ and the remaining $49,9 \%$ is influenced by other factors that are not included in the model used. The results of the $\mathrm{F}$ test show that the value of Fcount $=7,543$ is greater that the value of Ftable $=4,02$ at the 99\% level of confidence, so that the factors tested have a simultaneous effect on household food access in Tumbang Rungan Village, Pahandut District, Palangka Raya City. Partially, the last income and education of the head of the family has a significant effect on household food access in Tumbang Rungan Village, namely at the level of 95\% - 99\%, while those that do not significantly affect household food access in Tumbang Rungan Village are age and number of household members at the $90 \%$ confidence level.
\end{abstract}

Key words: access, food, household

\section{PENDAHULUAN}

Ketersediaan pangan tingkat nasional dan regional tidak menjamin adanya ketahanan pangan tingkat rumah tangga atau individu. Hal ini karena disamping ketersediaan pangan, ketahanan pangan rumah tangga individu sangat ditentukan pula oleh akses untuk mendapatkan pangan tersebut. Dalam hal ini, tingkat pendapatan dan daya beli merupakan faktor penentu akses rumah tangga terhadap pangan (Rosyadi \& Purnomo, 2012). Diperlukan upaya untuk menjalin kemitraan strategis antara pemerintah dan swasta guna meningkatkan kapasitas produksi pangan dan memperlancar distribusi pangan antar waktu, tempat dan golongan pendapatan (Suryana, 2014).
Pada tahun 2020, Indeks ketahanan pangan (IKP) Kota Palangka Raya seebsar 75,34 pada peringkat 54 kota. Tingkat pengeluaran pangan pada rumah tangga merupakan indikator untuk mengukur tingkat kesejahteraan. Semakin kecil persentase pengeluaran untuk makanan dibandingkan dengan non makanan dari seluruh pengeluaran maka semakin baik tingkat kesejahteraannya. Rata-rata persentase pengeluaran perkapita pertahun untuk makanan dan non makanan di Provinsi Kalimantan Tengah, dapat dilihat pada Tabel 1. 
Tabel 1. Rata-Rata Persentase Pengeluaran Perkapita Pertahun untuk Makanan dan Non Makanan di Provinsi Kalimantan Tengah, Tahun 2015 - 2019

\begin{tabular}{llllll}
\hline \multirow{2}{*}{ Tahun } & \multicolumn{2}{l}{ Makanan } & & & \multicolumn{2}{c}{ on Makanan } \\
\cline { 2 - 3 } & $\begin{array}{l}\text { Jumlah } \\
\text { (Rp) }\end{array}$ & $\begin{array}{l}\text { Persentase } \\
(\boldsymbol{\%})\end{array}$ & & $\begin{array}{l}\text { Persentase } \\
(\mathbf{R p})\end{array}$ & $(\mathbf{\%})$ \\
\hline 2015 & 5.938 .296 & 53,74 & & 5.111 .136 & 46,26 \\
2016 & 6.555 .672 & 52,29 & & 5.981 .568 & 47,71 \\
2017 & 7.459 .464 & 54,77 & 6.160 .296 & 45,23 \\
2018 & 7.589 .916 & 51,66 & 7.101 .768 & 48,34 \\
2019 & 7.809 .108 & 50,56 & & 7.637 .304 & 49,44 \\
\hline
\end{tabular}

Sumber: Badan Pusat Statistik (BPS) Provinsi Kalimantan Tengah, 2020

Berdasarkan data pada Tabel 1, menunjukkan bahwa dalam periode 5 tahun terakhir terjadi kenaikan tingkat pengeluaran masyarakat pada konsumsi makanan dan non makanan di Provinsi Kalimantan Tengah, yaitu selama kurun waktu dari tahun 2015-2019.

Ketahanan pangan suatu wilayah dikatakan baik apabila semua penduduknya setiap saat dapat memiliki akses terhadap pangan, walaupun pangan tersedia cukup di tingkat nasional dan regional, tetapi jika akses individu untuk memenuhi kebutuhan pangannya tidak merata, ketahanan pangan masih dikatakan lemah. Kemampuan dari ketersediaan pangan di tingkat nasional selalu mencukupi, tetapi tidak selalu menjamin ketahanan pangan di tingkat wilayah, rumah tangga dan individu. Hal tersebut dapat disebabkan oleh adanya keterbatasan akses terhadap pangan. Aksesibilitas yang terbatas akan berakibat pada kesulitan untuk mencukupi pangan yang bermutu dan bergizi, sehingga akan menghambat kesinambungan ketahanan pangan. Ketahanan pangan lokal harus dikembangkan dan diselaraskan dengan perkembangan modernisasi agar lebih mudah tercapai (Hakim, 2012).

Akses pangan merupakan aspek kritis dalam perwujudan ketahanan pangan selain ketersediaan dan pemanfaatan pangan, didukung dengan tersedianya infrastruktur fisik diantaranya adalah akses jalan, jembatan, ketersediaan lahan produktif, irigasi, gudang, lumbung pangan dan pasar. Terdapat dua kelompok mengenai akses terhadap bahan pangan. Akses langsung, yaitu dimana kemampuan individu memproduksi bahan pangan sendiri dan akses ekonomi (tidak langsung), yaitu kemampuan individu dalam memperoleh bahan pangan dengan membeli yang diproduksi dari tempat lain (Dinas Ketahanan Pangan Provinsi Kalimantan Tengah, 2018).

Akses pangan individu atau rumah tangga terdiri dari aspek ekonomi, fisik dan sosial. Aspek ekonomi tergantung pada pendapatan, kesempatan kerja dan harga. Aspek fisik menyangkut tingkat isolasi daerah (sarana dan prasarana distribusi) dan aspek sosial menyangkut tentang preferensi pangan (Adriani \& Wirjatmadi, 2012).

Akses pangan tinggi dan sangat tinggi, yaitu jika suatu rumah tangga dapat memenuhi kebutuhan pangan rumah tangganya yaitu dari segi akses ekonomi, akses fisik dan akses sosial. Akses pangan rendah dan sangat rendah, yaitu jika suatu rumah tangga tidak dapat memperoleh atau memenuhi kebutuhan pangan rumah tangganya, baik dari akses ekonomi, akses fisik maupun akses sosial. 
Studi lainnya terkait dengan ketahanan pangan, akses pangan dan faktor-faktor yang mempengaruhi akses pangan dapat dirujuk pada Suharyanto (2011); Rosyadi dan Purnnomo (2012); Ariani (2015); Rosmiati, dkk (2016); Wuryandari (2015).

\section{Permasalahan}

Permasalahan utama ketahanan pangan pada akses rumah tangga adalah pada aspek konsumsi yang terkait dengan pendapatan atau daya beli rumah tangga terhadap pangan. Konsumsi rumah tangga menggambarkan kondisi ketahanan pangan rumah tangga tersebut, terutama berkaitan dengan produksi, pendapatan keluarga, pengeluaran pangan, jumlah tanggungan keluarga, tingkat pendidikan dan ketersediaan pangan dalam rumah tangga.

Salah satu kelurahan yang ada di Kota Palangka Raya, adalah Kelurahan Tumbang Rungan, pada kelurahan ini mayoritas dari 174 rumahtangga mata pencaharian masyarakatnya sebagai nelayan, dikarenakan letak Kelurahan Tumbang Rungan berada dipinggir Sungai Kahayan, dengan pendapatan yang tidak tetap. Untuk produksi pangan dalam rumah tangga yang digunakan untuk konsumsi yang tersedia adalah ikan. Untuk pangan lainnya seperti padi-padian, umbiumbian dan sayuran tidak diproduksi, karena terkendala pada keadaan alam seperti banjir dari luapan air Sungai Kahayan yang sulit untuk diprediksi mengingat wilayah Kelurahan Tumbang Rungan merupakan daerah rawa yang permukaannya rendah.

\section{Tujuan}

Mengetahui akses pangan rumah tangga dan menganalisis faktor-faktor yang mempengaruhi akses pangan rumah tangga di Kelurahan Tumbang
Rungan Kecamatan Pahandut Kota Palangka Raya.

\section{METODE PENELITIAN}

Penelitian ini dilaksanakan di Kelurahan Tumbang Rungan Kecamatan Pahandut Kota Palangka Raya, dengan obyek penelitian adalah rumah tangga dengan jenis pekerjaan yang berbeda. Penentuan lokasi penelitian dipilih secara sengaja (purposive) berdasarkan pertimbangan tertentu seperti memiliki jumlah penduduk, rasio jenis kelamin dan jumlah rumah tangga terendah ditingkat Kecamatan Pahandut dan hampir setengah dari jumlah penduduknya masuk kategori penduduk miskin dan kepala keluarga miskin. Penelitian ini dilaksanakan selama tiga (3) bulan dari bulan November 2020 - Januari 2021.

Data yang dikumpulkan dalam penelitian ini data primer meliputi karakteristik rumah tangga, data akses pangan secara fisik, akses ekonomi dan akses sosial. Data primer diperoleh dari wawancara langsung terhadap rumah tangga dengan bantuan daftar pertanyaan (kuesioner) sementara data sekunder diperoleh dari instansi atau lembaga yang terkait dengan penelitian ini. Metode yang digunakan dalam pengambilan responden adalah rumah tangga yang dijadikan sebagai responden serta dipilih secara acak sederhana (simple random sampling). Dari 174 KK diambil 35 rumah tangga di Kelurahan Tumbang Rungan.

\section{HASIL DAN PEMBAHASAN}

\section{Karakteristik Rumah Tangga Responden}

Keadaan umum rumah tangga responden di Kelurahan Tumbang Rungan meliputi umur, suku, pendidikan terakhir, pekerjaan utama, 
pekerjaan sampingan, pendapatan dan jumlah anggota rumah tangga. Keadaan umum rumah tangga responden di
Kelurahan Tumbang Rungan dapat dilihat pada Tabel 2 berikut.

Tabel 2. Karakteristik Rumah Tangga Responden di Kelurahan Tumbang Rungan, Tahun 2020

\begin{tabular}{|c|c|c|c|}
\hline No. & Uraian & Jumlah & $\begin{array}{l}\text { Persentase } \\
(\%)\end{array}$ \\
\hline \multirow[t]{5}{*}{1.} & Umur Kepala Keluarga (Tahun): & & \\
\hline & a. Rata-Rata & 41 & 94 \\
\hline & b. Umur Minimum & 23 & 3 \\
\hline & c. Umur Maksimum & 65 & 3 \\
\hline & Jumlah & 35 & 100 \\
\hline \multirow[t]{5}{*}{2.} & $\begin{array}{l}\text { Pendidikan Terakhir Kepala Rumah Tangga (Orang): } \\
\text { a. Tidak Tamat SD }\end{array}$ & 3 & 9 \\
\hline & b. Tamat SD & 19 & 54 \\
\hline & c. Tamat SMP & 9 & 26 \\
\hline & d. Tamat SMA & 4 & 11 \\
\hline & Jumlah & 35 & 100 \\
\hline \multirow[t]{5}{*}{3.} & Pekerjaan Utama (Orang): & & \\
\hline & a. Nelayan & 31 & 89 \\
\hline & b. Tukang Bangunan & 2 & 6 \\
\hline & c. Tukang Kayu & 2 & 6 \\
\hline & Jumlah & 35 & 100 \\
\hline \multirow[t]{7}{*}{4.} & Pekerjaan Sampingan (Orang): & & \\
\hline & a. Tukang Bangunan & 5 & 14 \\
\hline & b. Nelayan & 4 & 11 \\
\hline & c. Menyadap Karet & 1 & 3 \\
\hline & d. Tukang Perahu & 1 & 3 \\
\hline & e. Tidak Ada & 24 & 69 \\
\hline & Jumlah & 35 & 100 \\
\hline 5. & Rata-Rata Jumlah Anggota Keluarga (Jiwa) & 4 & 100 \\
\hline 6. & Rata-Rata Pendapatan Rumah Tangga (Rp/Bulan) & 3.502 .000 & 100 \\
\hline
\end{tabular}

Sumber: Data Primer yang diolah, 2020

\section{Akses Pangan Rumah Tangga di Kelurahan Tumbang Rungan}

Untuk mengetahui akses pangan pada rumah tangga di Kelurahan Tumbang Rungan menggunakan metode pemberian angka (skoring) pada 35 responden rumah tangga yang ada di Kelurahan Tumbang Rungan. Hasil

Tabel 3. Indikator Akses Pangan Rumah Tangga di Kelurahan Tumbang Rungan, Tahun

\begin{tabular}{lllll}
2020 & & & \\
\hline \multirow{2}{*}{ No. } & Variabel & Uraian untuk Mengetahui Akses Pangan & Skor & \multirow{2}{*}{ Kriteria } \\
\cline { 2 - 3 } & Pendapatan & $\begin{array}{l}\text { Instrumen Pernyataan } \\
\text { banyak digunakan untuk membeli } \\
\text { pangan }\end{array}$ & 4 &
\end{tabular}

skoring menunjukkan bahwa akses pangan rumah tangga di Kelurahan Tumbang Rungan termasuk dalam kategori tinggi. Setiap rumah tangga dapat memenuhi kebutuhan pangan setiap harinya untuk setiap anggota rumah tangganya. 
Delika Parwati, Maleha, Tri Yuliana Eka Sintha
FAKTOR-FAKTOR YANG MEMPENGARUHI AKSES PANGAN
Kemiskinan

Harga Pangan

Daya Beli

Jumlah Anggota Rumah Tangga

Kepemilikan Lahan

Usia

2. Rumah tangga mempunyai pendapatan yang cukup untuk memperoleh bahan pangan sesuai kebutuhan dan pilihan setiap anggota rumah tangga

3. Kemiskinan dalam rumah tangga menyebabkan perbedaan perlakuan dalam pengaturan dan pembagian pangan antar anggota keluarga

4. Kemiskinan mempengaruhi akses 4 pangan rumah tangga

5. Kemiskinan mempengaruhi ketersediaan pangan rumah tangga dalam jumlah dan mutu yang memadai karena tidak dapat terpenuhi

6. Harga pangan di warung tidak jauh 4 berbeda dengan harga di pasar

7. Harga pangan mempengaruhi 4 pendapatan rumah tangga

8. Rumah tangga memiliki kemampuan daya beli yang baik terhadap kebutuhan pangan dengan menyesuaikan harga pangan, jenis pangan dan jumlah pangan yang dikonsumsi terhadap pendapatan yang diperoleh

9. Jumlah anggota rumah tangga berpengaruh terhadap porsi pengeluaran bahan pangan rumah tangga

10. Kepemilikan lahan yang digunakan untuk bekerja mempengaruhi anggota rumah tangga untuk menambah pendapatan keluarga

11. Pada usia > 50 tahun kemampuan kepala keluarga untuk bekerja guna meningkatkan pendapatan rumah tangga cenderung menurun

\begin{tabular}{llll} 
& \multicolumn{2}{c}{ tangga cenderung menurun } & 44 \\
\cline { 2 - 4 } 2. Akses Fisik & Ketersediaan Pangan & 12. Ketersediaan pangan di warung sangat & 4
\end{tabular}
memadai (lengkap)

13. Rumah tangga mendapatkan bahan 4 pangan dengan mudah yang sudah tersedia dilahan/kebun

14. Ketersediaan pangan rumah tangga 4 sebagian besar di produksi sendiri

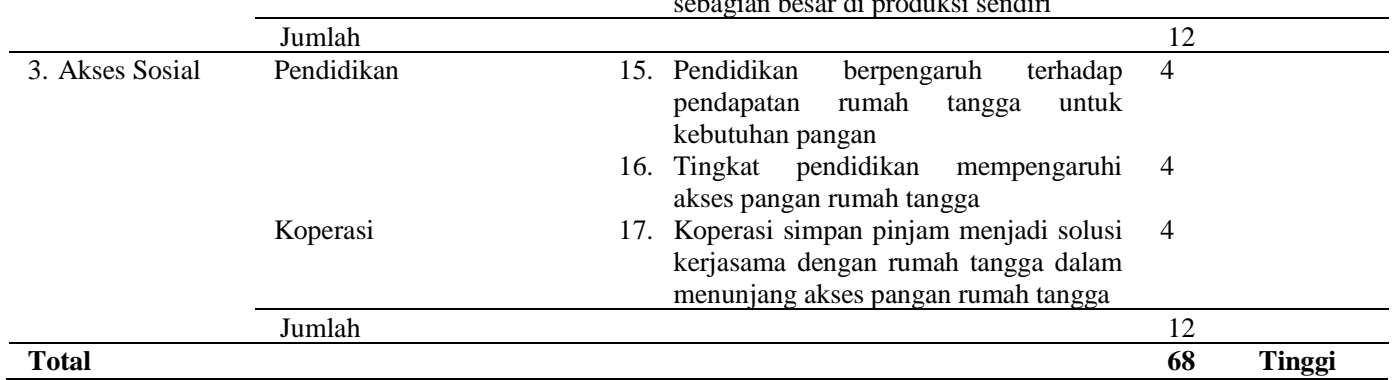

Sumber: Data Primer yang diolah, 2020

\section{Akses Ekonomi}

Hasil penelitian menunjukan bahwa semua variabel (pendapatan, kemiskinan, harga pangan, daya beli, jumlah anggota rumahtangga, kepemilikan lahan dan usia responden) memiliki skor rata-rata 4. Hasil penelitian menunjukan bahwa semua variabel (pendapatan, kemiskinan, harga pangan, daya beli, jumlah anggota rumahtangga, kepemilikan lahan dan usia responden) memiliki skor rata-rata 4. Semakin tinggi skor rataannya menunjukan semakin baik tingkat akses pangan rumahtangga tersebut.

\section{Akses Fisik \\ Ketersediaan pangan pada rumah tangga di Kelurahan Tumbang Rungan melalui akses fisik dapat dilihat dari}


ketersediaan pangan yang di produksi sendiri, kemudahan dalam mendapatkan bahan pangan di kebun atau alam serta ketersedian pangan yang dijual di warung cukup memadai. Skor rata-rata untuk ketersediaan pangan adalah 4, menunjukkan bahwa rumah tangga tersebut akses pangannya sudah baik. Untuk memenuhi kebutuhan pangan rumah tangga setiap anggota keluarganya, umumnya rumah tangga mengkonsumsi dari hasil usaha sendiri (mencari ikan) serta mencari sayuran lokal (rotan) yang terdapat di kebun atau tumbuh sendiri (tanaman liar) di alam. Untuk memperoleh pangan yang cukup, anggota rumah tangga dapat melakukannya dengan cara membeli, pinjam meminjam, bantuan pangan atau memalui pemberian orang lain. Keberadaan warung atau pasar yang menjual kebutuhan pangan di Kelurahan Tumbang Rungan, umumnya cukup memadai.

\section{Akses Sosial}

Hasil penelitian menunjukan bahwa semua variabel pada akses sosial (pendidikan dan koperasi) memiliki skor rata-rata 4. Semakin tinggi skor rataannya menunjukan semakin baik tingkat akses pangan rumahtangga tersebut. Pendidikan terakhir kepala keluarga dapat berpengaruh terhadap pendapatan rumah tangga dan juga tingkat pendidikan mempengaruhi akses pangan rumah tangga tersebut. Hal ini dikarenakan bahwa kepala keluarga memiliki kemampuan dalam mengatur pengeluaran pangan rumah tangga dengan pendidikan yang mereka peroleh, meskipun pendidikan yang mereka peroleh hanya mencapai pendidikan terakhir rata-rata SD.

Keberadaan koperasi simpan pinjam dapat menjadi solusi kerjasama dengan rumah tangga dalam meningkatkan akses pangan rumah tangga. Keberadaan koperasi juga sebenarnya dapat membantu rumah tangga dalam hal jual beli hasil usaha mencari ikan, khususnya di Kelurahan Tumbang Rungan sendiri, keberadaan koperasi masih belum ada.

\section{Analisis Faktor-Faktor yang Mempengaruhi Akses Pangan Rumah Tangga di Kelurahan Tumbang Rungan}

Akses pangan rumah tangga di Kelurahan Tumbang Rungan dipengaruhi oleh beberapa faktor, seperti umur $\left(\mathrm{X}_{1}\right)$, pendapatan $\left(\mathrm{X}_{2}\right)$, jumlah anggota rumah tangga $\left(\mathrm{X}_{3}\right)$ dan pendidikan terakhir kepala keluarga (D). Analisis yang digunakan untuk mengetahui pengaruh dari faktor-faktor tersebut terhadap akses pangan rumah tangga di Kelurahan Tumbang Rungan, maka digunakan uji regresi linear berganda menggunakan SPSS 16.

Tabel 4. Hasil Analisis Regresi Linear Berganda Akses Pangan Rumah Tangga di Kelurahan Tumbang Rungan

\begin{tabular}{lccc}
\hline \multicolumn{1}{c}{ Variabel } & $\begin{array}{c}\text { Koefisien } \\
\text { Regresi }\end{array}$ & t Hitung & Sig \\
\hline Konstanta $(\mathrm{a})$ & $75,036^{* * *}$ & 8,768 & .000 \\
Umur $\left(\mathrm{X}_{1}\right)$ &,- 227 & $-1,780$ & .085 \\
Pendapatan $\left(\mathrm{X}_{2}\right)$ & $1,123^{* *}$ & 2,129 & .042 \\
Jumlah anggota rumah tangga $\left(\mathrm{X}_{3}\right)$ & $-1,230$ &,- 684 & .499 \\
Pendidikan terakhir kepala keluarga $(\mathrm{D})$ & $13,879^{* * *}$ & 4,445 & .000 \\
\hline
\end{tabular}




\begin{tabular}{ll|r}
\hline Koefisien determinasi $\left(\mathrm{R}^{2}\right)$ & $=0,501$ & $\mathrm{t}_{\text {tabel }}: 99 \%=2,75000$ \\
Koefisien korelasi (R) & $=0,708$ & $95 \%=2,04227$ \\
F hitung & $=7,543$ & $90 \%=1,69726$ \\
F tabel $(99 \%)$ & $=4,02$ & \\
\hline
\end{tabular}

Sumber: Data Primer yang diolah, 2020

Persamaan regresi linear berganda faktor-faktor yang mempengaruhi akses pangan rumah tangga di Kelurahan Tumbang Rungan Kecamatan Pahandut Kota Palangka Raya, dapat ditulis sebagai berikut:

\section{$Y=75,036-0,227 X_{1}+1,123 X_{2}-$ $1,230 X_{3}+13,879 D$}

\section{a. $\operatorname{Umur}\left(\mathrm{X}_{1}\right)$}

Akses pangan rumah tangga di Kelurahan Tumbang Rungan dipengaruhi oleh beberapa faktor, salah satunya adalah umur $\left(\mathrm{X}_{1}\right)$. Hasil koefisien regresi umur $\left(\mathrm{X}_{1}\right)$ sebesar $-0,227$ dan $t_{\text {hitung }}=-1,780$ lebih kecil dari $t_{\text {tabel }}=1,69726$ pada taraf kepercayaan $90 \%$ dengan korelasinya negatif, sehingga umur $\left(\mathrm{X}_{1}\right)$ tidak berpengaruh nyata terhadap akses pangan rumah tangga di Kelurahan Tumbang Rungan. Didukung dengan keadaan di lapangan, bahwa pada umur > 50 tahun kepala keluarga masih mampu bekerja untuk memenuhi kebutuhan keluarga namun kemampuan bekerja cenderung menurun yang berpengaruh terhadap pendapatannya.

\section{b. Pendapatan $\left(\mathbf{X}_{2}\right)$}

Hasil koefisien regresi pendapatan $\left(\mathrm{X}_{2}\right)$ sebesar 1,123 dan $t_{\text {hitung }}=2,129$ lebih besar dari tabel $=2,04227$ pada taraf kepercayaan $95 \%$ dengan korelasinya positif, sehingga pendapatan $\left(\mathrm{X}_{2}\right) \quad$ berpengaruh terhadap akses pangan rumah tangga di Kelurahan Tumbang Rungan.
Dengan diperoleh nilai koefisien regresi sebesar 1,123 yang artinya jika pendapatan rumah tangga bertambah maka akses pangan rumah tangga meningkat sebesar $1,123 \%$. Semakin meningkat pendapatan rumah tangga, maka rumah tangga tersebut dapat memenuhi kebutuhan segala jenis bahan pangan yang diinginkan dan juga akan memberi peluang yang lebih besar bagi rumah tangga atau keluarga untuk memilih pangan dalam jumlah maupun jenisnya.

\section{c. Jumlah Anggota Rumah Tangga (X3)}

Setelah dilakukan analisis menggunakan regresi diperoleh hasil koefisien regresi jumlah anggota rumah tangga $\left(\mathrm{X}_{3}\right)$ sebesar $-1,230$ dan $t_{\text {hitung }}=-0,684$ lebih kecil dari $\mathrm{t}_{\text {tabel }}=1,69726$ pada taraf kepercayaan $90 \%$ dengan korelasinya negatif, sehingga jumlah anggota rumah tangga $\left(\mathrm{X}_{3}\right)$ tidak berpengaruh nyata terhadap akses pangan rumah tangga di Kelurahan Tumbang Rungan. Dengan diperolehnya nilai koefisien regresi sebesar -1,230 yang artinya jika jumlah anggota rumah tangga bertambah, maka kemampuan akses pangan rumah tangga tersebut akan menurun sebesar $-1,230 \%$. Hal ini disebabkan oleh jumlah anggota rumah tangga relatif kecil yaitu ratarata 4 orang, sehingga dalam pembagian pangan masih cukup merata oleh tiap anggota rumah tangga. 


\section{d. Pendidikan Terakhir Kepala Keluarga (D)}

Diperoleh hasil koefisien regresi sebesar 13,879 dan $t_{\text {hitung }}=4,445$ lebih besar dari $t_{\text {tabel }}=2,75000$ pada taraf kepercayaan $99 \%$ dengan korelasinya positif, sehingga pendidikan terakhir kepala keluarga (D) berpengaruh terhadap akses pangan rumah tangga di Kelurahan Tumbang Rungan. Dengan diperolehnya nilai koefisien regresi sebesar 13,879 yang artinya jika pendidikan terakhir kepala keluarga tinggi, maka akses pangan rumah tangga akan meningkat sebesar 13,879 .

\section{KESIMPULAN}

Akses pangan rumah tangga di Kelurahan Tumbang Rungan dari hasil analisis skoring yang digunakan dalam penilaian akses pangan, menunjukkan skor rata-rata dari aspek ekonomi, aspek fisik dan aspek sosial masing-masing sebesar 4. Semakin tinggi skor rataannya menunjukan semakin baik tingkat akses pangan rumahtangga tersebut.Total skor dari indikator akses ekonomi adalah 44, total skor indikator akses fisik 12 dan indikator akses sosial adalah 12. Total skor rataan dari indikator akses pangan sebesar 68 yang artinya bahwa akses pangan rumah tangga dalam kondisi tinggi. Semua variabel yang terdapat dalam 3 indikator berpengaruh terhadap akses pangan rumah tangga.

Akses pangan rumah tangga di Kelurahan Tumbang Rungan dipengaruhi oleh umur, pendapatan, jumlah anggota rumah tangga dan pendidikan terakhir kepala keluarga. Model yang digunakan dalam analisis ini berpengaruh sebesar $50,1 \%$ dan sisanya sebesar $49,9 \%$ dipengaruhi oleh faktor lain yang tidak masuk dalam model yang digunakan. Hasil uji $\mathrm{F}$ menunjukkan nilai $F_{\text {hitung }}=7,543$ lebih besar dari nilai $\mathrm{F}_{\text {tabel }}=4,02$ pada taraf kepercayaan $99 \%$, sehingga faktor yang diujikan memiliki pengaruh secara simultan terhadap akses pangan rumah tangga di Kelurahan Tumbang Rungan Kecamatan Pahandut Kota Palangka Raya. Secara parsial, pendapatan dan pendidikan terakhir kepala keluarga berpengaruh nyata terhadap akses pangan rumah tangga di Kelurahan Tumbang Rungan yaitu pada taraf $95 \%$ - 99\%, sedangkan yang tidak berpengaruh nyata terhadap akses pangan rumah tangga di Kelurahan Tumbang Rungan adalah umur dan jumlah anggota rumah tangga pada taraf kepercayaan $90 \%$.

\section{DAFTAR PUSTAKA}

Adriani, M. \& Wirjatmadi, B. (2012). Pengantar Gizi Masyarakat. Jakarta:Kencana Prenada Media Grup.

Ariani, M. (2015). Upaya Peningkatan Akses Pangan Masyarakat Mendukung Ketahanan Pangan. Dikutip dari: www.litbang.pertanian.go.id. Diakses pada 05 Maret 2020.

Badan Pusat Statistik. (2020). Kalimantan Tengah Dalam Angka 2020. Palangka Raya: Badan Pusat Statistik Provinsi Kalimantan Tengah.

Dinas Ketahanan Pangan Provinsi Kalimantan Tengah. (2018). Ketahanan Pangan Provinsi Kalimantan Tengah Tahun 2018. Palangka Raya: Dinas Ketahanan Pangan Provinsi Kalimantan Tengah.

Hakim, L. (2012). Akses Jadi Masalah Ketahanan Pangan Nasional. Dikutip dari: lipi.go.id/berita/single/akses-jadimasalah-ketahanan-pangan- 
nasional/6840. Diakses pada 30 Oktober 2019.

Rasmiati, H., Bakce, D. \& Khaswarina, S. (2016). Faktor Determinan Tingkat Ketahanan Pangan Rumah Tangga Peserta Program Desa Mandiri Pangan (DEMAPAN) di Provinsi Riau. Pekanbaru: Fakultas Pertanian Universitas Riau.

Rosyadi, I. \& Purnomo, D. (2012). Tingkat Ketahanan Pangan Rumah Tangga di Desa Tertinggal. Jurnal Ekonomi Pembangunan. Volume 13, Nomor 2. 303-315.
Suharyanto, H. (2011).Ketahanan Pangan. Jurnal Sosial Humaniora. Vol 4 No. 2. 186-194.

Suryana, A. (2014). Menuju Ketahanan Pangan Indonesia Berkelanjutan 2025: Tantangan dan Penanganannya. Forum Penelitian Agro Ekonomi. Volume 32 No. 2. 123-135.

Wuryandari, R. D. (2015). FaktorFaktor yang Mempengaruhi Pengeluaran Makanan, Pendidikan dan Kesehatan Rumah Tangga Indonesia (Analisis Data Susenas 2011). Jurnal Kependudukan Indonesia. Vol. 10. No. 1. 27-42. 